\title{
Influence of shoot inclination on irradiance and morphophysiological leaf traits along shoots in cerrado trees with distinct leaf deciduousness
}

\author{
João Paulo Souza ${ }^{1 *}$, Carlos Henrique B. A. Prado ${ }^{2}$, Maria A. Damascos ${ }^{3}$ \\ and Ana Lúcia S. Albino ${ }^{4}$
}
${ }^{1}$ Post-graduation program in Ecology and Natural Resources, Federal University of São Carlos, 13565-905, São Carlos, São Paulo, Brazil, joaopaulobio@hotmail.com, current address: Federal University of Viçosa, Campus Florestal, 35690-000, Florestal, Minas Gerais, Brazil.
2 Department of Botany, Federal University of São Carlos, 13565-905, São Carlos, São Paulo, Brazil, prado_chba@yahoo.com.br.
${ }^{3}$ National University of Comahue, Department of Botany, Quintral 1250, (8400) San Carlos de Bariloche, Argentina, damascos@crub.uncoma.edu.ar.
${ }^{4}$ Undergraduate of Biological Sciences, 13565-905, Federal University of São Carlos, São Carlos, São Paulo, Brazil, ana28_9@yahoo.com.br.

*Corresponding author. Fax: +55-31-35363300; Tel.: +55-31-35363300; e-mail: joaopaulobio@hotmail.com Received: 27 July 2009; Accepted: 13 December 2009.

\begin{abstract}
This study investigated the relationship among shoot inclination, irradiance and morphophysiological traits of basal (BL) and distal (DL) leaves in six cerrado trees with distinct leaf deciduousness. Deciduous species showed plagiotropic shoots $\left(44^{\circ}\right)$ and larger leaf area than semideciduous and evergreen species, which showed orthotropic shoots ( $56^{\circ}$ and $63^{\circ}$, respectively). Despite larger leaf area, irradiance at shoot base in deciduous was around $85 \%$ in relation to full irradiance, while in semideciduous and evergreen only $23 \%$ of irradiance reached on BL. Likewise, maximum net photosynthesis $\left(P_{n \max }\right)$ was similar between $B L$ and DL in deciduous. Contrastingly, semideciduous and evergreen showed significant decreasing of $\mathrm{P}_{\mathrm{nmax}}$ in BL. Plagiotropic shoots of deciduous allow similar irradiance along shoots, resulting in similar $\mathrm{P}_{\mathrm{nmax}}$ along shoot. On the other hand, orthotropic shoots of semideciduous and evergreen resulted in shading and decreasing of $P_{n \max }$ on $B L$. However, considering $B L$ and $D L$ together, there was not significant difference of leaf-life-span or $\mathrm{P}_{\text {nmax }}$ among deciduous, semideciduous and evergreen. Therefore, shoot inclination and shading among leaves on same shoot should be significant influencing leaf morphophysiological traits along shoots in cerrado trees. On the other hand, similar leaf-life-span among phenological groups resulted in absence of $P_{\text {nmax }}$ differences when $B L$ and $D L$ were considered together.
\end{abstract}

Key words: Leaf-life-span, maximum net photosynthesis, orthotropic, self-shading, plagiotropic.

\section{Resumo}

As relações entre a inclinação do ramo, irradiância e as características morfofisiológicas de folhas basais (FB) e distais (FD) foram investigadas em seis espécies arbóreas de Cerrado com distintas fenologias foliares. Espécies decíduas apresentaram ramos plagiotrópicos $\left(44^{\circ}\right)$ e maior área foliar do que espécies semidecíduas e sempreverdes com ramos ortotrópicos $\left(56^{\circ} \mathrm{e}\right.$ 
$63^{\circ}$, respectivamente). Nas espécies decíduas a irradiância solar foi de $85 \%$ na base do ramo, mas nas espécies semidecíduas e sempreverdes menos de $23 \%$ da irradiância incidiu nas FB. As decíduas apresentaram fotossíntese líquida máxima $\left(P_{\mathrm{nmax}}\right)$ equivalente entre FB e FD, porém, nas semidecíduas e sempreverdes ocorreu uma diminuição significativa de $P_{\text {nmax }}$ nas FB. Os ramos plagiotrópicos das decíduas permitiram uma equivalente irradiância solar e similar $\mathrm{P}_{\mathrm{nmax}}$ ao longo do ramo. De forma contrastante, os ramos ortotrópicos das semidecíduas e sempreverdes resultaram em intenso sombreamento e diminuição de $\mathrm{P}_{\text {nmax }}$ nas FB. Considerando conjuntamente $\mathrm{FB}$ e FD, não houve um gradiente significativo dos valores do tempo de vida da folha (TVF) ou $\mathrm{P}_{\text {nmax }}$ entre decíduas, semidecíduas e sempreverdes. A inclinação do ramo e 0 sombreamento correspondente entre as folhas são importantes fatores para a determinação de $\mathrm{P}_{\text {nmax }}$ ao longo dos ramos nas espécies arbóreas de Cerrado. Por outro lado, quando FB e FD foram consideradas conjuntamente não houve diferença de $\mathrm{P}_{\mathrm{nmax}}$ entre os grupos fenológicos estudados devido à similaridade do TVF.

Palavras-chave: Auto-sombreamento, fotossíntese líquida máxima, ortotrópico, plagiotrópico, tempo de vida foliar.

\section{INTRODUCTION}

Species with synchronic leaf production avoid leaf selfshading by displaying leaves in a flush on slanting (plagiotropic) shoots, where the irradiance is evenly distributed along shoot (Kikuzawa et al., 1996). In these species, similar availability of irradiance allows comparable photosynthetic capacity along plagiotropic shoots (Kikuzawa et al., 1996; Kikuzawa, 2003). Conversely, species with continuous leaf production show erect (orthotropic) shoots with basal leaves receiving lower irradiance than distal ones (Kikuzawa, 2003). Basal leaves on orthotropic shoots show lower maximum net photosynthesis $\left(P_{\text {max }}\right)$ and leaf mass per area than distal ones due to aging and shading effects (Kitajima et al., 2002; Mediavilla and Escudero, 2003). These relationships among shoot inclination, type of leaf production, leaf position on shoot, and $\mathrm{P}_{\mathrm{n} \max }$ are known in temperate environments (Kikuzawa et al., 1996; Kikuzawa, 2003). However, there is not information about shoot-foliage relationships in neo tropical savanna region, such as in Cerrado.

Cerrado sensu stricto is a vegetation physiognomy with slight light restriction to adult woody plants with shoots growing above herbaceous layer, where the canopies of trees rarely touch each other (Ribeiro and Walter, 1998). Only in dense woody Cerrado physiognomy (cerradão) the canopies touch each other frequently, performing a continuous layer that decreases the irradiance load on beneath strata (Kanegae et al., 2000). Despite great irradiance variability inside Cerrado physiognomies, there are few data about how leaf position along shoot and shoot inclination affect light incidence in these vegetation. Damascos et al. (2005b) investigated the effect of continuous leaf production on $\mathrm{P}_{\text {nmax }}$ along shoot in a potted evergreen cerrado species with orthotropic shoots (Leandra lacunosa Cogn.). Basal leaves of $L$. lacunosa showed lower $\mathrm{P}_{\text {nmax }}$ and leaf mass per area than the middle and apical shoot leaves, which could be a consequence of shading caused by new upper leaves on orthotropic shoots in L. lacunosa. Shading resulted by overlapping leaves and shoots inside tree crown could be more relevant in cerrado sensu stricto than the shading caused by neighboring crows.

Shading among leaves on same shoot and shoot inclination would be responsible for similarities or significant morphophysiological differences between basal and distal leaves on shoots in cerrado tree species (Damascos et al., 2005b). Synchronic leaf production in cerrado tree species (Paula, 2002; Damascos et al., 2005a; Damascos, 2008) probably takes place on plagiotropic shoots with leaves exposed to similar irradiance intensity, resulting in equivalent morphophysiological leaf traits in same shoot. On the other hand, evergreen and semideciduous cerrado tree species with continuous leaf production (Damascos et al., 2005a; Lenza and Klink, 2006; Damascos, 2008) likely have orthotropic shoots with significant shading among leaves, resulting in differences of morphophysiological traits between basal and distal leaves. Co-occurrence of deciduous, semideciduous and evergreen tree species in cerrado sensu stricto (Paula, 2002; Damascos et al., 2005a; Lenza and Klink, 2006) provides simultaneous comparison of leaf morphophysiological traits along shoot among species with distinct leaf deciduousness. In this study we analyzed the influence of shoot inclination and irradiance along shoots on morphophysiological traits of basal and distal leaves in six cerrado tree species with distinct patterns of leaf deciduousness. We hypothesized that leaf deciduousness necessarily is linked with shoot inclination and shading intensity 
among leaves in same shoot in trees growing in cerrado sensu stricto physiognomy such as in temperate environments (Kikuzawa et al., 1996; Kikuzawa, 2003). Specifically, we addressed the following questions about cerrado trees: (1) Are there differences in shoot inclination among tree species? (2) Are there differences in irradiance along shoots in tree species? (3) Do basal and distal leaves in same shoot differ about leaf morphophysiological traits? (4) Is there any relationship among leaf deciduousness, irradiance attenuation, shoot inclination, and leaf morphophysiological traits?

\section{MATERIALS AND METHODS}

Study area: The study was carried out in a cerrado sensu stricto physiognomy within a 86-ha protected area, in Federal University of São Carlos, São Paulo State, Brazil (21058'-2200' S and $47051^{\prime}-47052$ ' W). The regional climate is tropical with a dry season between April and September followed by a wet season between October and March (Prado et al., 2004; Damascos et al., 2005a; Monteiro and Prado, 2006). According to Köeppen climatic classification, the region is between Aw e Cwa. The local meteorological station recorded from 1939 to 2007 the annual average $( \pm S D)$ values of rainfall $(1420 \pm 168 \mathrm{~mm})$, and air temperature $\left(22 \pm 0.4^{\circ} \mathrm{C}\right)$. During the period of shoot inclination and leaf morphophysiological traits measurements (from 01/ March/2006 to 30/April/2006) the total rainfall was $22 \mathrm{~mm}$ and the mean air temperature $( \pm S D)$ was $22 \pm 1^{\circ} \mathrm{C}$. The soil of the study site was classified as distrophic oxisol, poor in nutrient, with water content from 0 to $3 \mathrm{~m}$ depth following the seasonal pattern of rainfall (Kanno, 1998). In the study area the canopies of trees rarely touch each other growing above a well-defined shrub and herbaceous strata, which characterizes a typical cerrado sensu stricto physiognomy (Ribeiro and Walter, 1998).

Plant species: The six tree species studied (Diospyros hispida, Kielmeyera variabilis, Casearia sylvestris Eriotheca gracilipes, Miconia ligustroides and Piptocarpha rotundifolia) were selected by being abundant in the study area (Oliveira and Batalha, 2005) and separated in three leaf phenological groups as described on Table 1: deciduous (DE), semideciduous (SD) and evergreen (EV). Five adult individuals of each species growing under full solar irradiance were marked for morphophysiological determinations. The pattern of leaf deciduousness was characterized according to Williams et al. (1997) and Paula (2002): DE species lose all leaves in dry season being leafless around 30 days, SD lose more than half of leaves in dry season and $\mathrm{EV}$ maintain almost the same area of foliage along the year.

Table 1. Mean $( \pm S E)$ values of height, circumference at breast height $(C B H)$, and leaf characteristics of six cerrado tree species studied. $D E=$ deciduous, $\mathrm{SD}=$ semideciduous, $\mathrm{EV}=$ evergreen, $\mathrm{SY}=$ synchronic, $\mathrm{CO}=$ continuous, $\mathrm{SP}=$ spiral, $\mathrm{AL}=$ alternate, $\mathrm{OD}=$ opposite and decusate, $\mathrm{SI}=$ simple, $\mathrm{CO}=\mathrm{compound}$.

\begin{tabular}{|c|c|c|c|c|c|}
\hline Species & $\begin{array}{l}\text { Height (cm) } \\
n=5\end{array}$ & $\begin{array}{c}\text { CBH (cm) } \\
n=5\end{array}$ & $\begin{array}{c}\text { Leaf } \\
\text { phenology }\end{array}$ & $\begin{array}{l}\text { Pattern of leaf } \\
\text { Production }\end{array}$ & $\begin{array}{c}\text { Phyllotaxy/ } \\
\text { Leaf type }\end{array}$ \\
\hline Diospyros hispida A. DC. (Ebenaceae) & $250 \pm 18$ & $16.6 \pm 1.4$ & $\mathrm{DE}$ & $S Y^{b}$ & $\mathrm{SP} / \mathrm{SI}$ \\
\hline Kielmeyera variabilis Mart. \& Zucc. (Clusiaceae) & $226 \pm 22$ & $20.4 \pm 3.4$ & $\mathrm{DE}$ & SY & $\mathrm{SP} / \mathrm{SI}$ \\
\hline Casearia sylvestris Sw. (Salicaceae) & $164 \pm 11$ & $8.6 \pm 0.4$ & SD & $\mathrm{CO}$ & $\mathrm{AL} / \mathrm{SI}$ \\
\hline Eriotheca gracilipes (K. Schum.) A. Robyns (Malvaceae) & $178 \pm 23$ & $13.6 \pm 2.7$ & SD & $\mathrm{CO}$ & $\mathrm{AL} / \mathrm{CO}$ \\
\hline Miconia ligustroides (DC.) Naudin (Melastomataceae) & $244 \pm 46$ & $13.8 \pm 3.3$ & EV & $\mathrm{CO}$ & OD/SI \\
\hline Piptocarpha rotundifolia (Less.) Baker (Asteraceae) & $238 \pm 43$ & $18.2 \pm 3.6$ & EV & $\mathrm{CO}$ & $\mathrm{AL} / \mathrm{SI}$ \\
\hline
\end{tabular}

${ }^{\mathrm{a} A c c o r d i n g ~ t o ~ P a u l a ~(2002) ~ a n d ~ o u r ~ p r e v i o u s ~ o b s e r v a t i o n ; ~}{ }^{\mathrm{b} D a m a s c o s}$ (2008)

Shoot inclination, irradiance along shoot and leaf-lifespan determination: Five adult individuals of each species were marked for determining the angle of shoot insertion of current-year shoots produced on growing season from September/2005 to March/2006. All morphophysiological measurements were carried out on current-year shoots. These shoots were easily identified by supporting green leaves, being at the periphery of the crown and on thicker parental leafless shoots. The angle of shoot insertion was determined in April 2006, at the end of growing period. A thin horizontal bar crossed by $2.0 \mathrm{~m}$ vertical bar was positioned at the insertion of each current-year shoot. A plummet was utilized to check the perpendicular position of the vertical bar. The thin horizontal bar was used as reference to determine the 
angle between the current-year shoot and the horizon using a compass. Ten current-year shoots in each individual were used for determining the mean value of the angle of shoot insertion ( $n=50$ shoots per species).

Irradiance on each leaf along the current-year shoot was determined at 12:00 h in April 2006 with a Phywe luxmeter (Göttingen, Germany). Full solar irradiance (considered as $100 \%$ ) was measured in open area of cerrado sensu stricto holding the luxmeter probe parallel to the solar beans. The luxmeter sensor on the top of the probe was placed at the side of each leaf along the current-year shoot, in same position of leaf blade in relation to solar beans. Therefore, the irradiance was not $100 \%$ even on distal leaves on shoot apex, because of leaf blades were not exactly at the right angle in relation to solar beans. Irradiance along shoot was determined in five current-year shoots in each one of five individuals previously marked ( $n=25$ shoots per species).

At the end of the dry season in July 2006, five buds were marked before its break in each one of five individuals of studied species for determining the leaf-life-span (LLS). Each bud marked was on distinct shoot in the crown. The LLS was determined since the leaf formation in August 2006 up to the leaf senescence on shoots originated from marked buds ( $n=25$ shoots per species). All new leaves on shoots were individually marked for determining LLS. The end of leaf-life was considered when the leaf became yellowish, about $90 \%$ of total leaf area, or when leaf fall took place.

Maximum net photosynthesis, chlorophyll index and leaf area: In March 2006, four current-year shoots in each one of five individuals in studied species were used for determining the maximum net photosynthesis $\left(\mathrm{P}_{\text {nmax }}\right)$ under saturation of photosynthetic photon flux density (PPFD) in basal (BL) and distal leaves (DL) on same shoots ( $n=20$ shoots per species). $\mathrm{P}_{\mathrm{nmax}}$ measurements were carried out in the morning between 08:00 and 10:00 h. An infrared gas analyzer (ADC, LCA-4, Hoddesdon, UK) functioning in a open mode was utilized for obtaining $P_{\text {nmax }}$ under PPFD of $1500 \mu \mathrm{mol} \mathrm{m}^{-2} \mathrm{~s}^{-1}$ (Prado and Moraes, 1997) provided by a light source (PLU-002, ADC) attached to a narrow Parkinson leaf chamber (PLCN-4, ADC). Peltier system (ADC) kept PLCN-4 at $25-27^{\circ} \mathrm{C}$. The leaf inside the PLCN-4 worked under $40-50 \%$ of air relative humidity and ambient $\mathrm{CO}_{2}$ concentration at $353 \pm 1 \mu \mathrm{mol} \mathrm{mol}^{-1}$. Only expanded BL and DL covering the whole PLCN-4 area (11.53 $\mathrm{cm}^{2}$ ), without damage, senescence, or pathogens were selected to $\mathrm{P}_{\mathrm{nmax}}$ determinations. The chlorophyll index (Chl) was obtained in March 2006 using the Chlorophyll Content Meter CCM-200 (Optical Science, Tyngsboro, USA) on each $B L$ and DL utilized for $P_{n \max }$ determinations. Three individuals of each species were utilized for leaf area (LA) determinations of $B L$ and $D L$ in March 2006, considering four current-year shoots in each individual ( $n=12$ shoots per species). Only one expanded $B L$ and $D L$ in each shoot were selected for LA measurements, according the same criteria for $P_{n \max }$ determinations. The image of each $B L$ and $D L$ was digitalized by a scanner and the area was determined in laboratory using the software Pro-Image version 4.0 (Media Cybernetics, USA).

Data analysis: Average values \pm standard error (SE) for all leaf traits, shoot inclination, and irradiance were calculated separately in each species and in every phenological group (deciduous, semideciduous and evergreen). KolmogorovSmirnoff test (Zar, 1999) was used for verifying normality in leaf traits data set (LLS, $P_{n \max }, L A$ and $\left.C h l\right)$, in percentage of irradiance and in shoot inclination.

Differences between $B L$ and $D L$ traits in each species were previously analyzed to determine the effect of leaf position along shoot. $P_{n \max }, L A$, and $\mathrm{Chl}$ were compared between $B L$ and $D L$ in each species and each leaf phenological group using a Student t test (Zar, 1999). The irradiance was compared between BL and DL in each species and in every leaf phenological group using the Mann-Whitney test.

Parametric variance analyzes (ANOVA) and pos-hoc Tukey test were used to investigate possible differences of LLS and shoot inclination among species separately or joined in corresponding leaf phenological group. The corresponding values of leaf traits ( $P_{\text {nmax }}, L A$ and $\left.C h l\right)$ from $B L$ and $D L$ were grouped and compared among all species. Grouped data related to leaf traits of $B L$ and $D L$ (species separately) did not show normal distribution and the Kruskal-Wallis test and the test of Dunn were used for verifying significant differences among species. The ANOVA and the Tukey test were used for checking differences of leaf traits among phenological groups with $\mathrm{BL}$ and $\mathrm{DL}$ grouped. One schematic representation about the relationship among light intensity, maximum net photosynthesis, leaf age, and shoot inclination in each leaf phenological group were performed according to Kikuzawa et al. (1996). 


\section{RESULTS}

The deciduous species (DE) Diospyros hispida and Kielmeyera variabilis have similar irradiance along shoots (Figure 1). In these DE species $85 \%$ of total irradiance, in average, reaches the leaf blades from the apex up to the base of the shoots. Contrastingly, semideciduous species (SD) Casearia sylvestris and Eriotheca gracilipes and evergreen species (EV) Miconia ligustroides and Piptocarpha rotundifolia showed a clear gradient of irradiance from the apex (75\%) to the shoot base, which showed less than $20 \%$ of total irradiance (Figure 1). Therefore, the percentage of irradiance did not differ $(p>0.05)$ between $B L$ and $D L$ in DE species (Table 2). On the other hand, it was measured only between $5-31 \%$ of total irradiance on BL in SD and EV species (Table 2).

There were not significant differences $(p>0.05)$ of $P_{n \max }$ between $B L$ and $D L$ in $D E$ species, in $S D$ species $C$. sylvestris and in EV species M. ligustroides (Table 2). Only C. sylvestris showed significant differences $(p<0.05)$ of Chlorophyll index (Chl) and leaf area (LA) between BL and DL (Table 2). Similarities or differences about morphophysiological traits between BL and DL were highlighted when it was analyzed considering species in leaf phenological groups (Table 3). Only SD and EV showed higher $\mathrm{P}_{\text {nmax }}$ in $\mathrm{DL}$ than $\mathrm{BL}$. There was not significant difference $(p<0.05)$ in irradiance between $B L$ and DL only in DE species. On the other hand, Chl and LA did not differ between BL and DL in any leaf phenological group (Table 3).

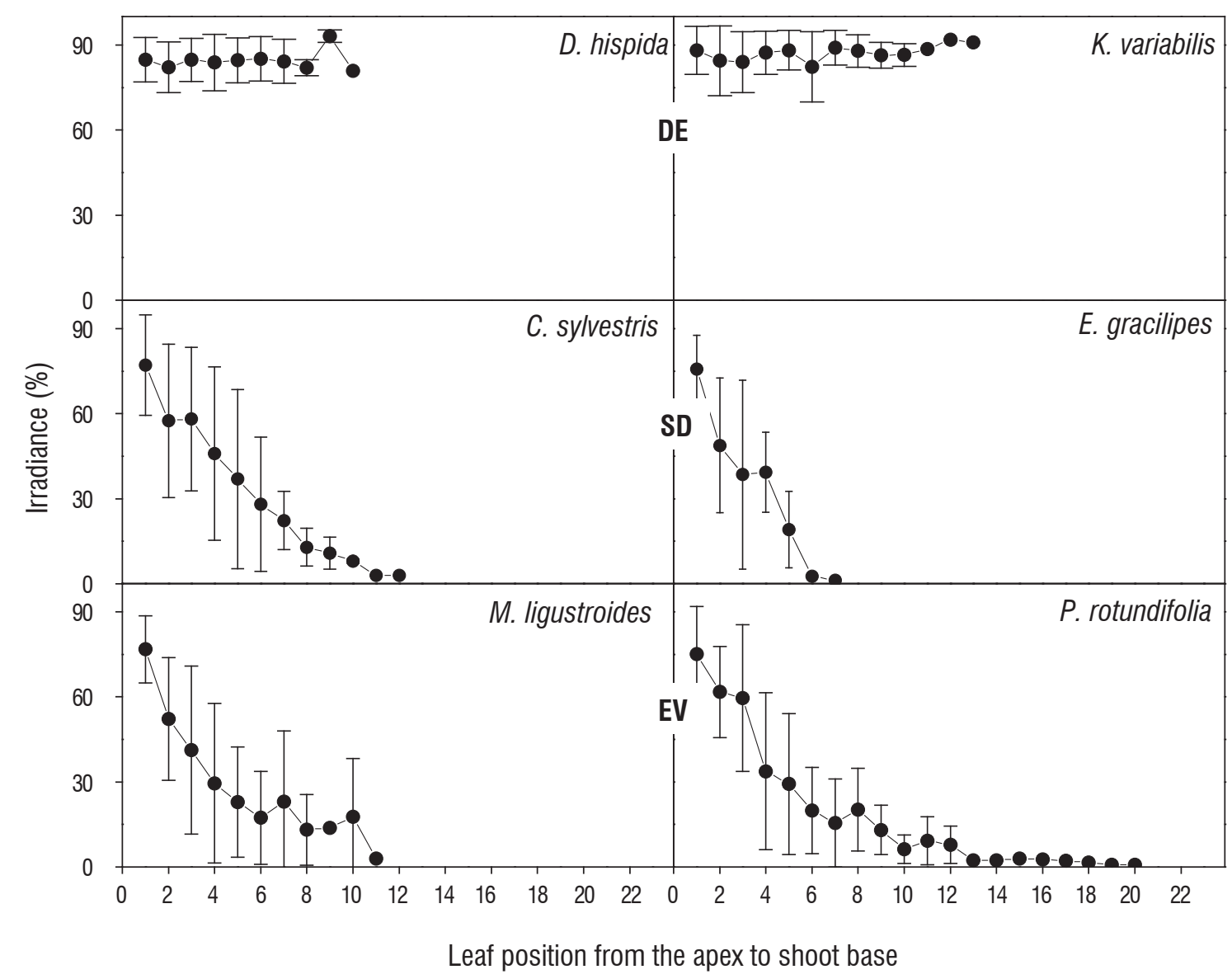

Figure 1. Irradiance (\%) from distal (position 1) to basal leaves along shoots of six cerrado tree species with distinct leaf deciduousness. Direct full irradiance in open area where tree species were growing was considered $100 \%$. $D E=$ deciduous, $S D=$ semideciduous, $E V=$ evergreen. $n=25$ shoots per species. 
Table 2. Morphophysiological traits and irradiance (mean values \pm SE) of basal $(B L)$ and distal (DL) leaves on shoots in six cerrado tree species with distinct leaf deciduousness. Different letters in line indicate significant differences between $\mathrm{BL}$ and $\mathrm{DL}$ in each species (Student $\mathrm{t}$ test, $p<0.05)$. Chl $=\mathrm{chlorophyll}$ index $(\mathrm{n}=20)$, $P_{n \max }=$ maximum net photosynthesis, $\mu \mathrm{mol} \mathrm{m}^{-2} \mathrm{~s}^{-1}(\mathrm{n}=20), \mathrm{LA}=$ leaf area, $\mathrm{cm}^{2}(\mathrm{n}=12), \mathrm{R}=$ incident radiation, percentage in relation to open area (100\%).

\begin{tabular}{|c|c|c|c|c|c|c|c|c|c|c|c|c|}
\hline \multirow{3}{*}{$\begin{array}{l}\text { Leaf } \\
\text { traits }\end{array}$} & \multicolumn{4}{|c|}{ Deciduous } & \multicolumn{4}{|c|}{ Semideciduous } & \multicolumn{4}{|c|}{ Evergreen } \\
\hline & \multicolumn{2}{|c|}{ Diospyros hispida } & \multicolumn{2}{|c|}{ Kielmeyera variabilis } & \multicolumn{2}{|c|}{ Casearia sylvestris } & \multicolumn{2}{|c|}{ Eriotheca gracilipes } & \multicolumn{2}{|c|}{ Miconia ligustroides } & \multicolumn{2}{|c|}{ Piptocarpha rotundifolia } \\
\hline & $\mathrm{BL}$ & $\mathrm{DL}$ & $B L$ & $\mathrm{DL}$ & $B L$ & $\mathrm{DL}$ & $B L$ & $\mathrm{DL}$ & $B L$ & $\mathrm{DL}$ & $B \mathrm{~L}$ & $\mathrm{DL}$ \\
\hline Chl & $43 \pm 3 a$ & $45 \pm 2 a$ & $19 \pm 1 \mathrm{a}$ & $16 \pm 1 \mathrm{a}$ & $28 \pm 1 \mathrm{a}$ & $22 \pm 2 b$ & $28 \pm 2 \mathrm{a}$ & $28 \pm 2 \mathrm{a}$ & $49 \pm 4 a$ & $42 \pm 4 a$ & $35 \pm 3 a$ & $31 \pm 3 a$ \\
\hline$P_{n \max }$ & $4.0 \pm 0.5 \mathrm{a}$ & $5.0 \pm 0.5 \mathrm{a}$ & $5.0 \pm 0.5 \mathrm{a}$ & $4.0 \pm 0.5 \mathrm{a}$ & $4.0 \pm 0.5 \mathrm{a}$ & $4.0 \pm 0.5 \mathrm{a}$ & $5.0 \pm 0.5 b$ & $6.0 \pm 0.5 \mathrm{a}$ & $4.0 \pm 0.5 \mathrm{a}$ & $5.0 \pm 0.5 \mathrm{a}$ & $5.0 \pm 0.5 b$ & $7.0 \pm 0.5 \mathrm{a}$ \\
\hline LA & $48 \pm 12 \mathrm{a}$ & $64 \pm 13 a$ & $35 \pm 4 a$ & $31 \pm 3 a$ & $7 \pm 1 \mathrm{a}$ & $3 \pm 1 b$ & $68 \pm 9 a$ & $49 \pm 9 a$ & $8 \pm 1 \mathrm{a}$ & $8 \pm 1 \mathrm{a}$ & $13 \pm 3 a$ & $12 \pm 2 \mathrm{a}$ \\
\hline $\mathbb{I R}^{\mathrm{a}}$ & $83 \pm 2 a$ & $84 \pm 2 a$ & $87 \pm 2 \mathrm{a}$ & $87 \pm 2 \mathrm{a}$ & $31 \pm 6 b$ & $76 \pm 4 a$ & $14 \pm 3 b$ & $77 \pm 4 a$ & $10 \pm 3 b$ & $76 \pm 2 a$ & $5 \pm 1 b$ & $74 \pm 5 a$ \\
\hline
\end{tabular}

aMann-Whitney

Deciduous species presented plagiotropic shoots, while SD and EV species showed orthotropic shoots (Table 4). Some trends were revealed in Table 4 considering morphophysiological traits of $B L$ and $D L$ joined in each studied species. The LLS and the leaf physiological traits (Chl and $\left.P_{\text {nmax }}\right)$ did not show a clear gradient among leaf phenological groups. On the other hand, LA decreased and shoot inclination increased from DE to EV. Therefore, morphological traits as LA and shoot inclination showed a clear gradient among phenological groups, but LLS and leaf physiological traits as $\mathrm{Chl}$ and $\mathrm{P}_{\text {nmax }}$ did not. Indeed, there was a clear decreasing of LA accompanied by increasing in shoot angle from DE to EV when both kinds of studied leaves and species were joined in corresponding phenological group (Figure 2). Thus, the results from Figure 2 confirmed what was found in Table 4; there is not a clear trend of variation about LLS and leaf physiological traits (Chl and $\mathrm{P}_{\mathrm{nmax}}$ ) but there is a clear gradient of morphological traits (LA and SI) among phenological groups.

The schematic representation of shoot and leaf growth at three differenttimes in Figure 2 reveals the interdependence among the kind of leaf production, shoot inclination and the irradiance intensity along shoots. Deciduous species have plagiotropic shoots, leaf production in a flush (synchronic, according to Damascos et al., 2005a; Lenza and Klink, 2006) and do not have significant differences of irradiance along shoots during the growth of new foliage. Contrastingly, semideciduous and evergreen studied species have orthotropic shoots, continuous leaf productions (according to Damascos et al., 2005a; Lenza and Klink, 2006) and significant irradiance attenuation from apex to the shoot base during the growth of new upper leaves.

Table 3. Morphophysiological leaf traits (mean values + SE) of basal (BL) and distal (DL) leaves in three leaf phenological groups (joined species) of six cerrado tree species. Mean values $( \pm \mathrm{SE})$ of incident radiation $(\mathrm{IR})$ are showed in relation to $100 \%$ obtained in open area. Different letters in line indicate significant differences (Student $\mathrm{t}$ test, $p<0.05)$ between $\mathrm{BL}$ and $\mathrm{DL}$ in same leaf phenological group. Chl=chlorophyll index $(\mathrm{n}=40), \mathrm{P}_{\mathrm{nmax}}=$ maximum net photosynthesis, $\mu$ mol $\mathrm{m}^{-2} \mathrm{~s}^{-1}$ $(\mathrm{n}=40), \mathrm{LA}=$ leaf area, $\mathrm{cm}^{2}(\mathrm{n}=24)$.

\begin{tabular}{|c|c|c|c|c|c|c|}
\hline \multirow{2}{*}{ Leaf traits } & \multicolumn{2}{|c|}{ Deciduous } & \multicolumn{2}{|c|}{ Semideciduous } & \multicolumn{2}{|c|}{ Evergreen } \\
\hline & $B L$ & $\mathrm{DL}$ & $B L$ & $\mathrm{DL}$ & $\mathrm{BL}$ & $\mathrm{DL}$ \\
\hline $\mathrm{Chl}$ & $31 \pm 2 \mathrm{a}$ & $31 \pm 1 \mathrm{a}$ & $28 \pm 1 \mathrm{a}$ & $25 \pm 2 a$ & $42 \pm 2 \mathrm{a}$ & $37 \pm 2 \mathrm{a}$ \\
\hline$P_{\text {nmax }}$ & $4.6 \pm 0.2 \mathrm{a}$ & $4.8 \pm 0.2 \mathrm{a}$ & $4.1 \pm 0.2 b$ & $5.0 \pm 0.3 a$ & $4.5 \pm 0.3 b$ & $6.1 \pm 0.3 \mathrm{a}$ \\
\hline LA & $42 \pm 6 a$ & $48 \pm 7 \mathrm{a}$ & $37 \pm 5 a$ & $26 \pm 5 \mathrm{a}$ & $10 \pm 2 \mathrm{a}$ & $10 \pm 1 \mathrm{a}$ \\
\hline $\mathbb{I R}^{\mathrm{a}}$ & $85 \pm 1 \mathrm{a}$ & $86 \pm 1 \mathrm{a}$ & $23 \pm 4 b$ & $76 \pm 3 a$ & $7 \pm 2 b$ & $75 \pm 3 a$ \\
\hline
\end{tabular}

aMann-Whitney 
Table 4. Mean values \pm SE of morphophysiological leaf traits considering basal and distal leaves together, the leaf-life-span (LLS) and the shoot inclination (SI) of six tree species of Cerrado with different leaf habitat. Different letters in line indicate significant differences $(p<0.05)$ among species. Chl $=$ chlorophyll index $(n=40)$, $\mathrm{P}_{\mathrm{nmax}}=$ maximum net photosynthesis $\left(\mu \mathrm{mol} \mathrm{m} \mathrm{m}^{-2} \mathrm{~s}^{-1}, \mathrm{n}=40\right), \mathrm{LA}=$ leaf area $\left(\mathrm{cm}^{2}, \mathrm{n}=24\right)$.

\begin{tabular}{|c|c|c|c|c|c|c|}
\hline \multirow{2}{*}{$\begin{array}{l}\text { Leaf traits and } \\
\text { shoot inclination }\end{array}$} & \multicolumn{2}{|c|}{ Deciduous } & \multicolumn{2}{|c|}{ Semideciduous } & \multicolumn{2}{|c|}{ Evergreen } \\
\hline & Diospyros hispida & Kielmeyera variabilis & Casearia sy/vestris & Eriotheca gracilipes & $\begin{array}{c}\text { Miconia } \\
\text { ligustroides }\end{array}$ & $\begin{array}{c}\text { Piptocarpha } \\
\text { rotundifolia }\end{array}$ \\
\hline $\mathrm{Chl}^{\mathrm{a}}$ & $44 \pm 2 a$ & $18 \pm 1 d$ & $25 \pm 1 c$ & $28 \pm 1 c$ & $45 \pm 3 a b$ & $33 \pm 2$ bc \\
\hline$P_{n \max }^{a}$ & $4.8 \pm 0.2 \mathrm{ab}$ & $4.5 \pm 0.3 a b$ & $3.7 \pm 0.2 b$ & $5.5 \pm 0.3 \mathrm{a}$ & $4.8 \pm 0.3 \mathrm{a}$ & $5.7 \pm 0.3 a$ \\
\hline $\mathrm{LA}^{\mathrm{a}}$ & $84 \pm 4 a$ & $41 \pm 1 b$ & $8 \pm 1 d$ & $71 \pm 6 a b$ & $10 \pm 1 d$ & $23 \pm 1 c$ \\
\hline $\mathrm{LLS}^{\mathrm{b}}$ & $256 \pm 6$ a & $183 \pm 3 c$ & $260 \pm 4 a$ & $220 \pm 4 b$ & $248 \pm 8 a b$ & $245 \pm 8 a b$ \\
\hline SI $\left({ }^{0}, n=50\right)^{b}$ & $46 \pm 3 c$ & $43 \pm 3 c$ & $59 \pm 3 a b$ & $53 \pm 3 b c$ & $66 \pm 2 \mathrm{a}$ & $59 \pm 2 a b$ \\
\hline
\end{tabular}

aKruskal-Wallis; ${ }^{b}$ ANOVA

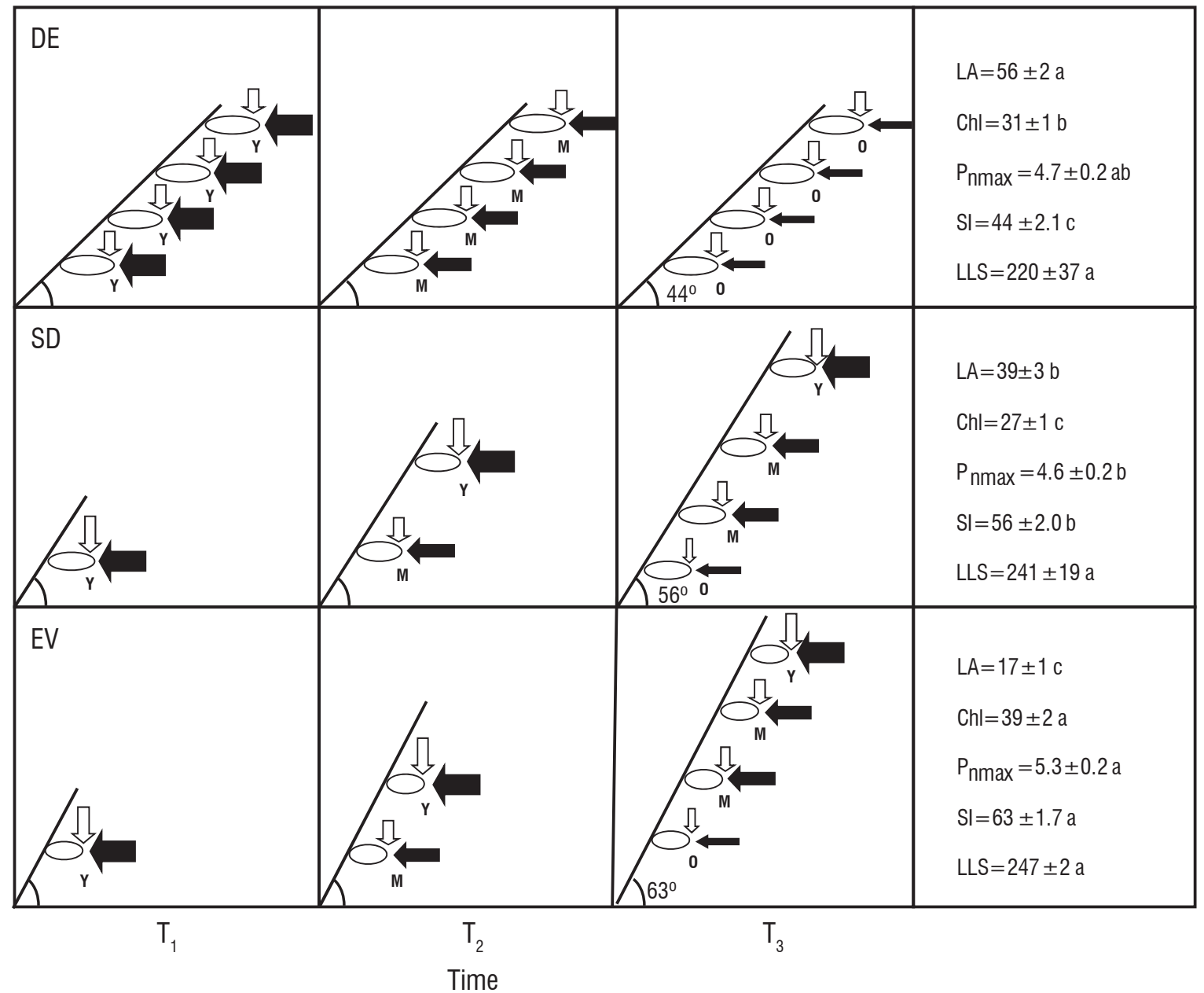

Figure 2. Schematic representation of shoot inclination, maximum leaf net photosynthesis, irradiance, type of leaf production, and leaf age on shoots of cerrado tree species as a function of time (T1, T2 and T3). The thickness of straight white arrow downwards represents the intensity of irradiance and the letters on the right of leaf indicates leaf age $(Y=$ young; $M=$ mature; $0=0$ ld). The thickness of black arrow in horizontal position represents the net photosynthetic rate intensity. Mean values of angle between shoot insertion and horizon are shown in each leaf phenological group in $T 3$ ( $D E=$ deciduous, $S D=$ semideciduous, $E V=$ evergreen). Mean values of leaf traits $+S E$ of basal and distal leaves together and the shoot inclination in each phenological group (joined species) are presented in right boxes. Different letters after mean values \pm SE in boxes indicate significant differences (ANOVA, $p<0.05$ ) among phenological groups in corresponding leaf trait or shoot inclination. LA=leaf area $\left(\mathrm{cm}^{2}, \mathrm{n}=48\right), \mathrm{Chl}=$ chlorophyll index $(\mathrm{n}=80), \mathrm{P}_{\mathrm{nmax}}=$ maximum net photosynthesis $\left(\mu \mathrm{mol} \mathrm{m}^{-2} \mathrm{~s}^{-1}, \mathrm{n}=80\right), \mathrm{Sl}=$ shoot inclination $\left({ }^{0}, \mathrm{n}=100\right)$, LLS=leaf-life-span. Based on Kikuzawa et al. (1996). 


\section{DISCUSSION}

Orthotropic shoots and continuous leaf production in SD and EV species probably are important traits intervening on $P_{\text {nmax }}$ in $B L$ and DL. Leaf age in orthotropic shoots of SD and $\mathrm{EV}$ species vary about months due to the continuous leaf production (Damascos et al., 2005a; Lenza and Klink, 2006). However, $P_{n \max }$ measurements were carried out at the end of the growing season in March, when the foliage did not show any signal of senescence. Therefore, the differences of $P_{n \max }$ between $B L$ and $D L$ found in SD and EV species should be a consequence of leaf shading caused by continuous leaf production in orthotropic shoots. Indeed, basal leaves in SD and EV species received between $7-23 \%$ of the total irradiance measured in open area (Table 3).

On the other hand, basal and distal leaves did not show differences of $P_{n \text { max }}$ in $D E$ species, probably due to similar irradiance along shoot during the leaf-life-span. Plagiotropic shoots in DE species could be a result of repeatedly addition of mass due to the synchronic leaf production (Kikuzawa et al., 1996). For instance, the DE species of Cerrado Bauhinia rufa (Bong.) Steud. showed less than 15 days of difference in age of leaves produced in same shoot (Damascos et al., 2005a). Besides, the shoot elongation in DE species occur within a short period after leaf bud break (Damascos et al., 2005a; Damascos, 2008), and expanded leaves should have a significant contribution in weight in immature shoots (Bozzuto and Wilson, 1988). Greater LA in DE than SD and EV probably is a consequence of low shoot inclination in DE. Plagiotropic shoots allows high leaf display avoiding the self-shading of the foliage in DE species (Figure 1) even with larger leaf area than SD and EV (Table 4 and Figure 2). On the other hand, SD and EV species showed low LA which results in an attenuation of shading among leaves in orthotropic shoots. In fact, there is a clear increase of shoot inclination and the opposite trend about LA from DE to EV.

In the previous work (Souza et al., 2009) we analyzed the influence of shoot inclination on biomass allocation pattern between shoots and leaves in cerrado trees and it was found that shoot inclination is a mean architectural trait in tree crown. The shoot inclination determines the amount of irradiance which reached on leaves along shoots and consequently the biomass allocation pattern between vegetative parts in tree crown. Deciduous species showed a similar irradiance along shoot and high biomass allocation in leaves than shoots. On the other hand, SD and EV species allocate higher biomass in shoots than leaves. Thus, in cerrado trees, shoot inclination, irradiance along shoot, and biomass allocation between shoots and leaves are linked with leaf deciduousness (Souza et al., 2009).

Unlike LLS and physiological leaf traits as $\mathrm{P}_{\mathrm{nmax}}$ and $\mathrm{Chl}$, the morphological characteristics showed a gradient of mean values among phenological groups. Similarities of physiological leaf traits could be a consequence of similar LLS among phenological groups. LLS seems to be an important trait that regulates some leaf physiological characteristics as $P_{\text {nmax }}$, nitrogen and phosphorus contents in temperate and tropical forest species (Reich et al., 1995; Reich et al., 1997; Reich et al., 1999). Species with low LLS need to have high photosynthetic capacity to cover quickly the costs of construction, defense and maintenance of leaves. On the other hand, species with high LLS have more time to carry out net photosynthesis and to return the resources invested in leaf (Reich et al., 1995; Reich et al., 1999). Therefore, leaves with high LLS usually presents an associated low photosynthetic capacity and low nitrogen and phosphorus contents. In cerrado sensu stricto, the studied tree species with distinct leaf deciduousness presented similar LLS. Therefore, the physiological leaf traits resulted in similar values (Figure 2). The pattern of leaf deciduousness is not related to LLS, but it is a consequence of several leaf cohorts produced continuously along the year in SD and EV species, which does not occur in DE with synchronic leaf production. Probably, the main trait that influences carbon gain among leaves in the same shoot in cerrado trees is the shoot inclination, which regulates the shading among leaves, and consequently, the light available inside the tree crown. Thus, the shoot inclination determines the similarities of morphophysiological traits between $\mathrm{BL}$ and $D L$ in $D E$ and the differences between these leaves in SD and $\mathrm{EV}$. On the other hand, comparable values of LLS determine the absence of differences of physiological leaf traits among phenological groups.

In conclusion, the higher shading among leaves in orthotropic shoots in SD and EV species is an important feature influencing $P_{\text {max }}$ in $B L$ and $D L$. These species present low leaf area likely for avoiding foliage self-shading and only newer distal shoots leaves receive high irradiance. The older basal leaves in orthotropic shoots in SD and EV species are intensely shaded, showing low $P_{\text {nmax }}$. On the other hand, $D E$ 
species have plagiotropic shoots allowing similar irradiance along shoot, which results in similar $\mathrm{P}_{\mathrm{nmax}}$ between $\mathrm{BL}$ and $\mathrm{DL}$ and allows high leaf area without intense foliage self-shading. Similar LLS among studied tree species explains similarities of $\mathrm{P}_{\text {nmax }}$ in distinct phenological groups, because these leaves have same time to cover the costs of allocated resources in their machinery.

Acknowledgements: JPS and CHBAP acknowledge the scholarships awarded by Conselho Nacional de Desenvolvimento Científico e Tecnológico, CNPq - Brazil, and to Dr. Gustavo Maia Souza e Dr. Rafael Ribeiro by stimulating criticism of the manuscript.

\section{REFERENCES}

Bozzuto LM, Wilson BF (1988) Branch angle in red maple trees. Can. J. For. Res. 18: 643-646.

Damascos MA, Prado CHBA, Ronquim CC (2005a) Bud composition, branching patterns and leaf phenology in Cerrado woody species. Ann. Bot. 96:1075-1084.

Damascos MA, Ronquim CC, Prado CHBA (2005b) Gas exchange and plant growth after defoliation on Leandra lacunosa, a cerrado woody species with continuous leaf production. Braz. Arch. Biol. Techn. 48:967-974.

Damascos MA (2008) Conteúdo das gemas, momento da brotação e padrão de produção de folhas em espécies lenhosas do cerrado [online]. Available from http://fisiologiavegetal.manole.com.br/textos\%20corrigidos/ rhdamascos.pdf [accessed 16 December 2009].

Kanegae MF, Braz VS, Franco AC (2000) Efeitos da seca sazonal e disponibilidade de luz na sobrevivência e crescimento de Bowdichia virgilioides em duas fitofisionomias típicas dos cerrados do Brasil Central. Rev. bras. Bot. 23:459-468.

Kanno SS (1998) Estudo ecofisiológico de duas espécies nativas do cerrado: Kielmeyera coriacea e Kielmeyera variabilis - A disponibilidade hídrica e sua relação com as trocas gasosas, o potencial hídrico foliar e a fenologia. São Carlos, Federal University of São Carlos, PhD thesis.

Kikuzawa K, Koyama H, Umeki K, Lechowicz MJ (1996) Some evidence for an adaptive linkage between leaf phenology and shoot architecture in sapling trees. Funct. Ecol. 10:252-257.
Kikuzawa K (2003) Phenological and morphological adaptations to the light environment in two woody and two herbaceous plant species. Funct. Ecol. 17:29-38.

Kitajima K, Mulkey SS, Samaniego M, Wright SJ (2002) Decline of photosynthetic capacity with leaf age and position in two tropical pioneer tree species. Am. J. Bot. 89:1925-1932.

Lenza E, Klink CA (2006) Comportamento fenológico de espécies lenhosas em um cerrado sentido restrito de Brasília, DF. Rev. bras. Bot. 29:627-638.

Mediavilla S, Escudero A (2003) Photosynthetic capacity, integrated over the lifetime of a leaf, is predicted to be independent of longevity in some tree species. New Phytol. 159:203-211.

Monteiro JAF, Prado CHBA (2006) Apparent carboxylation efficiency and relative stomatal and mesophyll limitations of photosynthesis in an evergreen cerrado species during water stress. Photosynthetica 44:39-45.

Oliveira FF, Batalha MA (2005) Lognormal abundance distribution of woody species in a cerrado fragment (São Carlos, southeastern Brazil). Rev. bras. Bot. 28:39-45.

Paula NF (2002) Capacidade fotossintética, deciduidade e teor de nitrogênio e fósforo em espécies lenhosas do cerrado. São Carlos, Federal University of São Carlos, PhD thesis.

Prado CHBA, Moraes JAPV (1997) Photosynthetic capacity and specific leaf mass in twenty woody species of Cerrado vegetation under field conditions. Photosynthetica 33:103-112.

Prado CHBA, Wenhui Z, Rojas MHC, Souza GM (2004) Seasonal leaf gas exchange and water potential in a woody cerrado species community. Braz. J Plant Physiol. 16:7-16.

Reich PB, Walters MB, Kloeppel BD, Ellsworth DS (1995) Different photosynthesis-nitrogen relations in deciduous hardwood and evergreen coniferous tree species. Oecologia 104:24-30.

Reich PB, Walters MB, Ellsworth DS (1997) From tropics to tundra: Global convergence in plant functioning. Proc. Natl. Acad. Sci. 94:13730-13734.

Reich PB, Ellsworth DS, Walters MB, Vose JM, Gresham C, Volim JC, Bowman WD (1999) Generality of leaf traits relationships: a test across six biomes. Ecology 80:1955-1999.

Ribeiro JF, Walter BMT (1998) Fitofisionomias do Bioma Cerrado. In: Sano SM, Almeida SP (eds), Cerrado: Ambiente e Flora, pp.89-166. EMBRAPA, Planaltina, Brasil.

Souza JP, Prado CHBA, Albino ALS, Damascos MA (2009) Shoot-foliage relationships in deciduous, semideciduous, and evergreen cerrado tree species. Braz. J Plant Physiol. 21: 75-86.

Williams RJ, Myers BA, Muller WJ, Duff GA, Eamus D (1997) Leaf phenology of woody species in a north Australian tropical savanna. Ecology 78:2542-2558. Zar JH (1999) Biostatistical analysis. $4^{\text {th }}$. Prentice Hall, New Jersey. 